\title{
A Greek-speaking Jew in the land of the Himyarites?
}

\author{
Prof Magdel le Roux \\ Department of Biblical and Ancient Studies \\ University of South Africa (Unisa) \\ E-mail: Lrouxm1@unisa.ac.za \\ https://orcid.org/0000-0002-0770-7303 \\ Doi: https://doi.org/10.46222/pharosjot.102.025
}

\begin{abstract}
Some scholars believe that 'genuine' Jews were present in Yemen as early as the $10^{\text {th }}$ to the $6^{\text {th }}$ century BCE. The Himyarite Kingdom saw another phase of Judaization between the $4^{\text {th }}$ and $6^{\text {th }}$ centuries CE. The history of Judaism in Southern Arabia is interlinked with the other two major religions of our time, namely Christianity and Islam, both of which were also practised in the area. The spread of the religions was inevitable as the interconnectedness of cultures and religions increased through political and trade relationships. This paper focuses on the nature of the 'non-converted' Jewish community in Yemen. The discovery of a Greek inscription in the ruins of a synagogue at Qanī (South Yemen) adds additional knowledge about the nature of the Jews of Himyar. Is this an isolated case? When and where were the Jews exposed to the Greek culture? In 1936 and 1937, Mazar revealed a remarkable system of tombs in Bĕţ Śĕ' 'ārīm (Qiryat Tib'on) in northern Israel (near Haifa) and showed that these tombs were those of the Jews of Himyar. The cemetery served as a burial place for Jews from various regions after the diaspora in late antiquity. It is furthermore 'notable that the inscriptions at the Himyari tombs in Bĕţ Śè 'ārīm are in Greek, next to an interlacing of Epigraphic South Arabian script. Apparently, it often happened that Jews of Himyar sent the bodies of their relatives to be buried in Israel. A review and analysis of the historical literature will be employed. An epigraphic and archaeological approach illuminates this investigation.
\end{abstract}

Keywords: Greek-speaking Jews, Yemen, synagogue Qanī, archaeology, Bĕţ Śŭ 'ārīm, epigraphical sources.

\section{Introduction}

It is believed that 'genuine' Jews were present in the area of Yemen as early as the 10th to the $6^{\text {th }}$ century BCE (cf. Le Roux, 2017:572; Torrey, 1933:131-133). According to the folklore of Yemenite (Sabaean) Jews, their ancient forebears migrated from Palestine to Yemen, 'exactly forty-two years before the destruction of the first temple' (Goitein, 1969:226-235; Tobi, 1986:56-65). From the biblical narrative (in I Kings 10:11-15; Genesis 10:29) itself the tradition rests on trade between the Land of Israel and Yemen since the days of Solomon and the Queen of Sheba. ${ }^{1}$

\footnotetext{
${ }^{1}$ The Old Testament refers to the 'kingdom of Saba' from which the famous Queen of Sheba came to visit King BC, established in Ethiopia as is proved by the characteristics of the Ethiopian language and writing as well as the oral traditions of the Lemba in Southern Africa (Gayre of Gayre, 1972:89). Mathivha (1992:1-7) suggests that the 'Jewish' ancestors of the Lemba migrated from 'the North' to Yemen as traders in the $7^{\text {th }}$ century BC, where they established a large community at a place called Sena.
} 
The Himyarite Kingdom saw another phase of Judaization between the 4th and 6th centuries $\mathrm{CE}$ - before it became Christian. Inscriptions from the Himyarite Kingdom shows the presence of Judaism in the 4th century CE. Judaism seems to have been a major religion of the upperclass citizens, though perhaps not for the entire kingdom. Muslim sources from the early 5th century AD support the theory of Jewish people in southern Arabia (Yule, Franke, Meyer, Nebe, Robin \& Witzel 2007:511). The history of Judaism in Southern Arabia is interlinked with the other two major religions of our time, namely Christianity and Islam, both of which were also practised in the area. The Himyarite Kingdom (Arabs), or Himyar, historically referred to as the Homerite Kingdom by the Greeks and the Romans, was a polity in the southern highlands of Yemen, as well as the name of the region which it claimed. They dominated the spice trade and many kingdoms around them sought their spices. The spread of the religions was inevitable as the interconnectedness of cultures and religions increased as the result of political and trade relationships. Monumental works about Judaism in Yemen have already been published (by Robin, 2003; 2008; Gajda, 2009; Hirschberg, 1946; Goitein, 1983; and others), but they had at their disposal only limited epigraphic material2.

The Martyrdom of Saint Arethas and his companions (MA), The Acts of Saint Gregentius (Acts) and the Syriac source, The Book of the Himyarites, complete the evidence of epigraphy and archaeology (in Christides, 2015:27). These two sources provide valuable information about the Himyarites and the Ethiopians who invaded the Himyarite Kingdom in 525 AD (Christides, 2013:80-106). 'It was known by Greek and Oriental historiographers that a Himyarite king of South Arabia, who converted to the Hebraic religion, had tormented Christian Arabs in Nejran and for their revenge, the Negus of Ethiopia had invaded South Arabia, killed the Himyarite King in 525 CE, and enthroned a Christian king' (Pirenne, 1974:119).

The purpose of this paper is not only to focus on the complicated subject of the Jewish nature of the Judaized Himyari kingdom (c. AD 375-525), but also to draw attention to the exposure of the Jews of Himyar to Greek culture. The discovery of a Greek inscription (ca. 2nd century $A D$ ) in the ruins of a synagogue at Qanī (South Yemen), as well as other archaeological and epigraphic sources, add to our knowledge of the Jews of Himyar.

\section{Inscriptions and other sources}

Southern Arabia has yielded inscriptions ${ }^{3}$ in various languages, including Ge'ez, Hebrew and Greek, the presence of which indicates foreign influences and domination throughout its history (Robin, 2009b: online). Except for a few small hints, Jewish sources have ignored the existence of a Jewish presence in Yemen (Tobi, 2013:349) and 'for many years scholars were

\footnotetext{
'In the view of the maritime undertakings of King Solomon and later some of the Judaean kings in the Red Sea, it is not far-fetched to assume that some Judaeans settled in Yemen in that early period' (Goitein, 1969:226). Goitein makes it clear that no historical record of such settlement has been found thus far, but their presence is attested for the centuries immediately preceding Islam by Islamic and Christian sources, as well as by local inscriptions written in the Himyarite language. These sources also bear witness that the Jews in Yemen were in close contact with their co-religionist in Palestine and that they proselytised vigorously in their adopted country (Goitein, 1969:227). Goitein (1969:227) stresses that the flourishing Christian elements in Yemen disappeared under Islamic rule, but Judaism stood firm throughout the history of that country. In Yemen, another oral tradition, which constitutes a tradition of the Lemba, still exists, namely that a group of Jews left Yemen centuries ago (how long is not certain) for Africa, and did not return (Parfitt 1995:5).

${ }^{2}$ Robin and Gajda report that their religious beliefs were a modus vivendi that included fasting, special dietary rules, name changes, respecting the Sabbath, circumcision, etc.

${ }^{3}$ Inscriptions give insights into antique populations and their languages. In particular, they reflect valuable information about the elite members of a society (Robin, 2009b:online).
} 
reluctant to recognize Himyar's monotheism as Jewish, because there had not been contemporary proof of the religion as Jewish' (Mikanowski, 2013:3).

Recent archaeological and epigraphic discoveries strongly suggest that many Himyarites were in fact Jewish, and that many of them came from Israel, not Yemen (Mikanowski, 2013:3).

In 1936 and 1937, Mazar revealed a remarkable system of tombs in Bĕţ Śè' 'ārīm (Qiryat Tib'on) in northern Israel (near Haifa) and showed that these tombs were those of the Jews of Himyar (Hirschberg, 1946:53-57, 283-284). The cemetery served as a burial place for Jews from various regions after the diaspora in late antiquity (Mikanowski, 2013:3). Apparently, it often happened that Jews of Himyar sent the bodies of their relatives to be buried in Israel.

Naveh (2003:624) published a Sabaean-Hebrew-Aramaic inscription that had been engraved over a Himyari tomb early in the 5th century AD. The inscription was discovered near So'ar, a Jewish town bordering the western shore of the Dead Sea. The Jews of Himyar's strong spiritual attachment to their land (Israel) is also attested to by an inscription bearing the names of the priestly wards found (in 1970) near Ta'im, east of San'a (Urbach, 1973:304-327). It was a 'monumental inscription engraved in Hebrew script on a huge stone pillar that was apparently placed in a Jewish synagogue in a fairly remote place' (Tobi, 2013:352). All other inscriptions found used the Sabaic language of the Himyarite kingdom.

Another Sabaean-Hebrew-Aramaic inscription from the beginning of the 5th century $A D$, engraved over a Himyari tomb refers to a person who died in the city of Zafar, the land of the Himyaris (Naveh, 2003:624). Zafär ${ }^{4}$ in Oman (eastern Haḍramawt) and the island of Saqutra were the markets for incense according to Pliny (Nat. Hist. 62.32). The Periplus states explicitly that Arabians, Indians and 'Greeks who sail[ed] out for commerce established communities there' (in Andrade, 2017:50). Excavations at Zafar (done by Yule, from the University of Heidelberg) revealed a 2nd century chamber that some scholars believe to be a Mikveh (Jewish ritual bath) and reliefs with Jewish images (Mikanowski, 2013: online).

Yemenite oral traditions and the biblical narratives are not accepted as scientific evidence (in some academic circles), but the tombs in Běţ Śĕ 'ārīm disclose important information about the existence of an ancient Jewish community in Yemen. Scholars are 'inclined to draw a connection between the first settlement of the Jews in Yemen and the Himyari tombs' of either the 1st or 2nd century AD. Hirschberg (1946:53-54) argues it was 'a long enough period of time for the Jews of Yemen to become established in their new settlement, before sending them to be buried in the Land of Israel in the third century'.

Furthermore, a seal stone discovered in a Himyari cemetery in Zafär, with a depiction of a Torah Ark, is believed to be the earliest evidence of the presence of Jews in Yemen. The seal stone was dated as early as the 2nd century AD (Yule, 2005:28; 2007:94-95). This Jewish presence in Yemen 'provide[s] the background to the alternative history of the Ark of the Covenant, as told by folk etymologies and old Arabic texts until the eighth century. The eighth century Arab historian Wahb ibn Munabbib and others claim that the hidden Ark was discovered by the Jurhum tribe, which controlled parts of north-western Arabia, in the sealed cave where Jeremiah had hidden it and that they took the Ark to Mecca' (in Parfitt, 2008:211, $212)^{5}$. According to Parfitt $(2008: 113,114,210-213)$ Arabic sources indicate that those Jews in Yemen had the Ark of the Covenant and they used it against their enemies on the Peninsula

\footnotetext{
${ }^{4}$ Zafār or Dafar is an ancient Ḥimyarite site situated in Yemen, some $130 \mathrm{~km}$ south-south-east of today's capital, Sana'a. Zafār was the capital of the Hiimyarites from 110 BCE to 525 CE.
} 
(Parfitt, 2008:113, 114, 210-213; Le Roux, 2009:102-125). Parfitt (2008:218) 'records the wide belief in the Wadi Hadramaut that the Ark had been hidden in a sealed cave, perhaps in the Wadi Hadramaut itself. Lions and snakes protect the secret of the place' (cf. Le Roux, 2009:108).

More recently, Lemaire and Bron (2009) published a c. 600 BC Sabaic inscription that also refers to trade relations between towns in Judea and Yemen. Although the early 6th century $\mathrm{BC}$ inscription helps us to determine the possible beginning of a Jewish settlement in Yemen, it should of course also affect scholars' attitude towards the Yemenite oral traditions and the many references to the Land of Israel and the Queen of Sheba in the books of the Bible (Robin, 1992-1996; Lemaire, 2002). Unfortunately, it still does not shed light on the nature of the settlement (Tobi, 2013:350).

\section{Greek Inscriptions}

Robin (2009b) states that the importance of Greek as a global language is attested to in Periplus Maris Erythraei, which dates from the 1st century AD and states that the ruler of what is modern-day Ethiopia was 'well versed in reading and writing Greek' (Robin, 2009b: online).

A few examples of Greek graffiti were discovered in South Arabia - three in Qanī and two in Nejran, where churches were built in the 6th century according to the Acts of Gregentius (Christides, 2015:33). Robin (2009a:169) suggests that 'these graffiti were most probably not written by local Greek-speaking Himyarites but by Byzantine visitors, most likely traders ${ }^{6}$. Greek was something of a 'cosmopolitan language' and was used (among other languages) by traders and travellers who moved between Egypt and the Indian Ocean. These travels meant that many Greek-speaking people moved around and settled in foreign lands. Western India was one such a place where Greek speakers (Yavanas) settled and created an IndoGreek kingdom (Andrade, 2017:42-43). Trade between western India and southern Arabia was common and cross-pollination was likely. During the Hellenistic period (323 BC to $30 \mathrm{BC}$ ), the Greek language and culture spread throughout what had once been the Persian Empire. Until Arab influence became prominent (7th century AD), speaking Greek and having a Greek education were important in the lives of the privileged (Burstein 2008:41).

Apparently, Jews from Himyar were buried in a prestigious place near the tombs of the Sanhedrin (Tobi, 2013:351). Although it was considered an outstanding virtue not to be buried in foreign countries but in the Land of Israel, for some religious reasons the custom of bringing the deceased from the Diaspora to be buried in the Land of Israel was harshly criticised by a certain Amora of the Land of Israel in the Jerusalem Talmud (Ketubbot 66a).

The point is that the Himyaris were obviously worthy of being buried in the Land of Israel because they were known and respected in the eyes of those who dwelt in the Land of Israel during their lifetime. An eight-character Himyari ligature refers to one Himyari, a person by the name of Menahem, who was called by the epithet qyl hmyr (prince of Himyar), while in the Greek inscription he was called Menae presbyteros (Menahem, the community's elder). A name, in Greek letters, of a woman in the genitive form was also found: Ev入oyía $\zeta$, meaning either 'virtue', 'blessing' or 'gratis' (Hirschberg, 1946:56-57; 33, pl. b.).

Arabic sources record that during the eve of the rise of Islam, most of the population in Haḍramawt were proselytized Jews (Lecker, 1995) and, according Muslim historian Ya 'qubi 
(d. 897/8), all the inhabitants of Yemen were Jews on the eve of Islam (Goitein, 1983:135138).

During the 1950s, Phillips discovered the ruins of a Jewish synagogue dating from the 4th century AD at the foot of the citadel wall in Ta'izz (1955:196). Numerous Sabaic inscriptions discovered in different places attest to a number of synagogues in ancient Yemen (Tobi, 2013:353).

Of greater importance is the disclosure of a Jewish synagogue in Qanī, 'dating back to the second half of the third century AD' (Tobi, 2013:352), as it provides information on issues that have never been known or discussed before (cf. Bowersock, 2010; Patrich, 2011) - it shows that the extent of the Jewish settlement in Yemen was much greater than expected (Tobi, 2013:352).

Qanī or Kanê (alternative spelling) Bi 'r Ali means 'Ali's well' in Arabic. Qanī was the name of a port in pre-Islamic times (Rougelle \& Benoist, 2001) and a village in eastern Yemen, located in the Shabwah Governorate. Qanī was of great economic importance. Several Greek and Latin sources (Periplus Maris Erythraei; Pliny the Elder's Historia Naturalis; Claudius Ptholmaeus' Geography) mention that it was 'the chief port city of Hadramawt and the marketplace for trade in aromatic spices and condiments which passed through northern Africa' (Tobi, 2013:350). It was the main shipping port on the Indian Ocean, serving traders on their way to both East Africa and India, but it was also the first station along the Incense Route, which led from there in a northerly direction to Shabwah and Ma'rib.

It is plausible that foreigners moved to and lived in Yemen based on different archaeological finds. Mediterranean style art (made in Yemen) and Greek inscriptions dated to around the 2nd century AD indicate that there was a definite link between Himyar and the Mediterranean (Yule et al, 2007:486) at that stage.

For the purpose of this paper, the discovery of a relatively long Greek inscription (five lines), inside the synagogue at Qani (South Yemen) is of single importance (Tobi, 2013:353). The

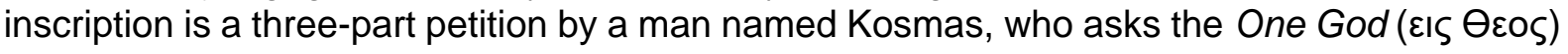

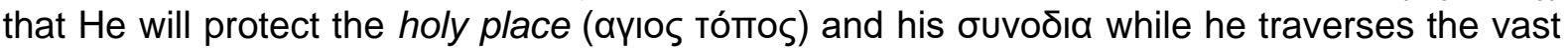

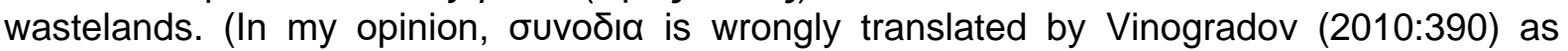
'caravan'; Bowersock's translation 'religious association' makes much more sense [Bowersock 2010:3]).

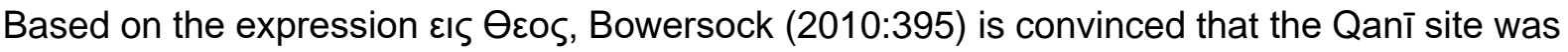
a Jewish synagogue rather than a Christian church ${ }^{7}$. It is furthermore 'notable that the inscriptions at the Himyari tombs in Bĕţ Sé 'ārīm are in Greek, next to an interlacing of Epigraphic South Arabian script and they too, contain the expression عıऽ $\Theta \varepsilon \circ \varsigma$ as well as ayı тómoৎ. Burial cave from Bĕţ Ś 'ārīm has a Greek inscription from the 4th or 5th centuries AD stating that the graves "belonged to the Himyarites". Thus, religious Jews from Himyar sought to be returned to the "Jewish Homeland" as their eternal resting place' (Mikanowski 2013: online).

As stated above, the inscription raises a question about the exposure of the Jews of Himyar to Greek culture. 'The epigraphic texts thus far discovered confirm that some Himyari Jews used Hebrew, Aramaic, and Sabaic, including a Hebrew and Aramaic component within the

\footnotetext{
${ }^{7}$ Two hagiographical sources, namely $M A$ and Acts, report that churches were built in Qani during the 6th century $\mathrm{AD}$ (MA, § 38, 6-10, pp. 282-283; Acts, Bios, p. 394, lines 150-160).
} 
Sabaic' (Tobi, 2007:48-49). Patrich (2011:104 and others) are convinced that the use of Greek suggests that Kosmas, the author of the inscription, was a merchant from abroad and not one of the local people. Hirschberg (1946:54), however, argues that the Greek names on the Himyari tombs in Běţ Śĕ 'ārīm prove that they or those who buried them were influenced by Greeks. Now, with the discovery of the Greek inscription in Qanī (referring to عıऽ Өعoऽ as well as aүıऽ тómoऽ), we have no need for such an explanation of the presence of Greek culture among the Jews of Himyar.

\section{Conclusion}

The discovery of the Greek inscription at the synagogue in Qanī has enriched our knowledge of the Jews of Himyar. It has shed light on certain anecdotes that we did not fully comprehend previously. Increased interconnectedness between different cultures and religions as a result of political and trade relationships inevitably led to the spreading of religions. The presence of Jews in Yemen (since the 10th to the 6th century BC) and Greek-speaking Jews (at least since the 2nd century AD) are attested to by numerous examples of graffiti, inscriptions, seal stones, tomb stones and synagogues found all over the Arabian Peninsula (and some in Israel). In the light of the numerous archaeological and other discoveries in- and outside Yemen, it is clear that 'knowledge of the Greek language and its culture was widespread among the Jews of Himyar, or at least among some of them' (Tobi, 2013:354). The Jewish community in the Himyarite Kingdom was a vital one (Tobi, 2013:354).

\section{References}

Andrade, N.J. (2017). Drops of Greek in a multilingual sea: The Egyptian network and its residential presences in the Indian Ocean. Journal of Hellenic Studies 137, 42-66.

Bowersock, G.W. (2010). The Greek inscription from South Yemen, in Salles, J.F. \& Sedov, A. (eds), Qāni, le port antique du Hadramawt entre la Méditerranée, I 'Afrique et l'Inde. Tunrnhout: Brepols, 3-8.

Burstein, S.M. (2008). When Greek was an African language: The role of Greek culture in ancient and Medieval Nubia. Journal of World History 19(1), 41-61.

Christides, V. (2013). 'Roman and Byzantine naval power in decline in the Red Sea and the Indian Ocean.' Ekklesiatikos Pharos 95, 80-106.

Christides, V. (2015). 'The dawn of the urbanization in the Kingdom of the Himyarites in the $6^{\text {th }}$ century and in the light of Byzantine hagiography', in Christides, V. (ed), Interrelations between the peoples of the Near East and Byzantium in Pre-Islamic times. Cordoba: CNERU-DTR-Oriens Academic, 25-48.

Gajda, I. (2009). Le Royaume de Himyar à l'epoque monothéiste. Paris: Mémoires de l'Académie des inscriptions et Belles Lettres.

Gayre of Gayre, R. (1972). The origin of the Zimbabwean civilisation. Salisbury: Galaxie.

Goitein, S.D. (1969). 'The Jews of Yemen', in Arthur Arberry (ed), Religion in the Middle East: three religions in concord and conflict, Vol I. Cambridge, 226-235.

Gotein, S.D. (1983). Ha-Temanim. Jerusalem: Ben Zvi Institute. 
Hirschberg, H.Z. (1946). Yisrầ'él ba- 'Arab. Tel Aviv: Ben Zvi Institute.

Lecker, M. (1995). The conversation of Himyar to Judaism and the Jewish Banũ Hadl of Medina. Die Welt des Orients 26, 129-136.

Lemaire, A. (2002). La Reine de Saba à Jérusalem: la tradition ancienne re-considérée, in Hübner, U. \& Knauf, E.A. (eds), Kein Land für sich allein: Studien zum Kulturkontakte in Kanaan, Israel/palästina uns Ebirnäri für Manfred Weippert zum 65 Geburtstag (OBO 186). Freiburg: Universitätverlag, 43-45.

Lemaire, A. \& Bron, F. (2009). Nouvelle inscription sabéenne et le commerce en Transeuphratène. Transeuphratène 38, 11-29.

Le Roux, M. (2009). Ngoma lungundu: an African Ark of the Convenant. Old Testament Essays 22, 102-125.

Le Roux, M. (2017). Judaism in the Sabaean 'Kingdom': Oral world, material culture and written word, in Christides, V. (ed), Proceedings for the $13^{\text {th }}$ International congress on GraecoOriental and African Studies and colloquium East and West: Greek-Arabic relations. Athens: Herodotos, 572.

Mathivha, M.E.R. (1992). The Basena/Vamwenye/Balemba. Morester: Mathivha.

Mikanowski, J. (2013). Yemen, the crucible of al-Qaida, was once a powerful Arabian kingdom run by Jews. Tablet (online).

Naveh, J. (2003). Ketobet qeber du-lesonit mi-Seba. Lesonemu 65, 117-120.

Parfitt, T. (1995). Africa and Zion. The case of the Lemba, in Kaplan, S., Parfitt, T., Semi, E.T., Between Africa and Zion. Proceedings of the first international congress of the Society for the study of Ethiopian Jewry. Jerusalem: SOSREJ Ben-zvi Institute.

Parfitt, T. (2008). The lost Ark of the Covenant. The remarkable quest for the legendary Ark. London: Harper-Collins.

Patrich, J. (2011). Bet keneset Yehudi qadum be-ir ha-namal Qanī se-be-Teman. Qadmoniyyot 142, 102-106.

Phillips, W. (1955). Qataban and Sheba. Exploring ancient kingdoms on the biblical spice routes of Arabia. New York: Harcourt \& Bruce.

Pirenne, J. (1974). 'A palaeographical chronology of the Sabaean-dated inscriptions, with reference to several eras'. Proceedings of the Seminar for Arabian Studies 4, 119.

Robin, C. (1992-1996). Seba II dans les inscriptions de l'Arabie du Sud, in Briend, J., Quesnel, M. (eds), Supplément au dictionnaire de la Bible. Xii. Paris: Letouzey \& Ané, Cols 1047-1254

Robin, C. (2003). Le Judaisme de Himyar. Arabia 1, 97-172.

Robin, C. (2008). Joseph, dernier roi de Himyar (de 522 à 525, ou une des années suivantes). Jerusalem Studies in Arabic and Islam 34, 1-124. 
Robin, C. (2009a). 'Inventaire des documents épigraphiques provenant du royaume de Himyar aux IVe - Vle siéles', in Robin, C. \& Schiettecatte, J. (eds), L'Arabie à la veille de I'slam. Paris: De Boccard, 169-204.

Robin, C.J. (2009b). Arabia and Ethiopia, in Johnson, S.F. (ed) (2009). The Oxford handbook of late antiquity. Oxford: Oxford University Press. Online.

Rougelle, A. \& Benoist A. (2001). 'Notes on pre- and early Islamic harbours of Hadramaut (Yemen).' Proceedings of the Seminar for Arabian Studies 31, 203-214.

Tobi, Y. (1986). ‘lyyūnīm bi-mgillat Temān. Jerusalem: The Magnes.

Tobi, Y. (2007). Ha-qěhillāh ha-yěhūdīt bě-Hāşī, děrōm Tēmān, bět ha-kěneset 'Şūrî’ěl' u-bět ha-qěbārōt śebāh. Tema 10, 41-56.

Tobi, Y. (2013). The Jews of Yemen in light of the excavation of the Jewish synagogue in Qanī? Proceedings of the Seminar for Arabian Studies, Vol 43, Papers from the Forty Sixth meeting of the Seminar for Arabian Studies held at the British Museum, London. 13 to 15 July 2012, 349-356.

Torrey, C. (1933). The Jewish foundation of Islam. New York: Jewish Institute of Religion.

Urbach, E.E. (1973). Mismarot u-ma ‘amadot. Tarbiz 42, 304-327.

Vinogradov, Ju. G. (2010). Une inscriptions grecque sur le site de Bir 'Ali (Qāni), in Salles, J.F. \& Sedov, A. (eds), Qāni, le port antique du Hadramawt entre la Méditerranée, I 'Afrique et I'Inde. Tunrnhout: Brepols, 389-392.

Yule, P. (2005). Zafar - the capital of the ancient Himyarite Empire rediscovered. JemensReport, 22-29.

Yule, P. (2007). Himyar: Spätantique im Jemen - Late Antique Yemen. Aichwald: Linden Soft. Yule, P.A., Franke K., Meyer, C., Nebe, G.W., Robin, C. and Witzel, C. (2007). Zafār, capital of Himyar, IBB province, Yemen. Archäologische Berichte aus dem Yemen 11, 479-547. 